\title{
ENVIRONMENTAL POLLUTION AND SUSTAINABILITY OR THE IMPACT OF THE ENVIRONMENTALLY CONSCIOUS MEASURES OF INTERNATIONAL COSMETIC COMPANIES ON PURCHASING ORGANIC COSMETICS
}

\section{Nora Amberg ${ }^{1 *}$, Robert Magda ${ }^{2}$}

'Doctoral School of Management and Business Administration, Department of Marketing Methodology, Faculty of Economics and Social Sciences, Szent Istvan University, Gödöllö, Hungary

IInstitute of Economics, Law and Methodology, Faculty of Economics and Social Sciences, Szent István University, Gödöllő, Hungary

Our research deals with environmental pollution, sustainability, and the impacts made by international cosmetic companies on the motivation of purchasing organic cosmetics. Unfortunately, our environment is becoming more and more polluted, which affects our planet Earth on a global scale. It is everybody's responsibility to decrease the environmental load, diminish our ecological footprint and leave a much cleaner and safer environment to the future generation in line with the principles of sustainable development. We have examined global environmental problems, the efforts made by international cosmetic companies to protect the environment and their impact on the preference, selection and purchase of environmentally friendly cosmetics. Nowadays, efforts of significant importance are prioritised that are more and more shifted to health and environmental consciousness regarding both corporate and consumer behaviour.

Keywords: organic cosmetics, sustainability, environmental pollution, cosmetic corporations, environmentally friendly consumer behaviour

All of us are responsible for the condition of the Earth in our micro cosmos. Corporations, states and governments are expected to show examples of how to live a more environmentally conscious life and think of the future generations while considering the principle of sustainable development.

Our environment, i.e. the place surrounding the humans, is where we live and work. This environment is practically similar to the living space of wildlife, i.e. the biosphere that is populated by living organisms.

Our environment consists of different parts that could be organic and inorganic alike, natural or artificial (man-made).

The different parts of the environment are in close relationship and the harmful effects on one of them will also have an impact on the entire environment, and finally, it can even harm human life globally.

In the geobiological units changes are circular where the organic and inorganic matters cannot be separated so the environmental problems are caused by ecologically harmful human interventions that disrupt the equilibrium of nature.

\section{Material and methods}

Regarding methodology, expository and descriptive secondary research was conducted in the cosmetic market of the USA and Europe primarily based on the data of Allied Market Research Report 2014-2022 and Cosmetics Europe.

\section{Results and discussion}

\section{The process of environmental pollution}

Environmental pollution is a human activity directed at negatively changing the properties of elements in nature, which significantly degrades the living conditions.

The primary process of environmental pollution starts from the emission of polluting agents through their transmission to mankind and their possessions (immission) where their polluting effect is determined by the extent of pollution.

Regarding the origins of pollution, a distinction must be made between industrial, agricultural, traffic, municipal and other sources. On the basis of their nature, sources can be fixed or mobile source pollutants and also there is a difference between point source and non-point source pollution. Emission may be temporary or permanent, steady or fluctuating. The pollutants can also be labelled as toxic-non-toxic and organic-inorganic ones.

These polluting agents modified by transmission can do damage to the immediate or broader environment. As pollution is spreading, its impact will diminish, i.e. dilute but there are cases like those of different chemical transformations where the impacts can become even stronger. The (chemical, physical, biological) condition of the medium that transmits the damage will also affect transmission such as the relief conditions and those of flow. 
Immission is the term describing the value of pollution at a point. It can refer to the concentration of a pollutant in the air caused by the aggregate effect of the emission of all sources modified by the transmission. No part of it can directly be felt and their impact will result in harmful consequences after a longer period.

Introvert emissions have an impact on the internal part of the source (industrial plant), employees, objects and instruments while the extrovert ones will affect people and goods outside the establishment. It is easier and more local to protect against introvert emission and the extrovert ones will pose a more dangerous threat to society as they are more widespread.

The environment changes due to human activity, which can be useful as well as harmful. In return, the environmental pollution can also affect the humans but usually it is shifted in time and space. The effects are different on the natural and man-made environment, respectively, as while it is easier to reconstruct the man-made environment, the processes can sometimes be irreversible in the natural environment such as the extinction of plant and animal species.

To date, environmental pollution has reached such alarming proportions that the situation may only be partially rectified by properly established institutions as well as measures and also by surveying the harmful impacts of human activity in advance so that they could only have minimum adverse impacts or no impacts at all.

A large number of natural resources utilised such as minerals and ores are transformed into hazardous waste. Moreover, the natural resources such as air and water are polluted by wastes, so nowadays the inevitable natural resources are gradually diminishing (Moser et al., 1992).

Thus, environmental pollution has reached such alarming proportions that we are talking about a global challenge that can only be curbed by international cooperation.

Such global environmental problems include:

$\square$ overpopulation, poverty, famine;

$\square$ the impact of production on the environment and mankind (mining and metallurgy);

$\square$ the impact of consumption on the environment (tourism, municipal consumption and waste);

$\square$ forms of destroying wildlife by non-pollution (overfishing, overgrazing);

$\square$ adverse environmental processes caused or accelerated by man (soil erosion);

$\square$ environmental pollution;

$\square$ waste generation;

$\square$ the state of the Earth, signs of its modified operation (global climate change, ozone depletion, acidity, polluting the global ocean, the state of the biosphere, destruction of the gene resources, gene erosion);

$\square$ a slower pace of the growth of food production;

$\square$ the dearth of water resources and their contamination;

$\square$ endangering biodiversity;

$\square$ depleting non-renewable natural resources;

$\square$ the exposedness of mankind to health hazards (Kerényi 1995, Buzás et al., 2004).

\section{Environmental protection solutions}

The most important objective of environmental pollution is to ensure the health and prosperity of men (and the future generations) by means of adequate living conditions and protecting tangible and intangible assets. It is not only a protective measure but such a planned series of actions on improving the environment that transforms our environment simultaneously with preventing harm.

Environmental protection is the complex system of such measures whose objective is:

$\square$ protection by preventing damage;

$\square$ stopping damage done;

$\square$ improving man-made environment;

$\square$ applying feasible solutions with natural resources.

Important parts of environmental protection include nature protection and conservation.

Nature protection puts parts of the natural environment rich in natural values under protection by limiting and possibly eliminating the economic and other activities of mankind and eliminating the harmful effects on the environment by restoring the original state and preserving the natural values. It preserves fresh air, water, flora and fauna and the natural ecological conditions.

In contrast, conservation deals with the protection of the artificial, manmade environment. Its objective is organising human activity without doing any harm to humans and their natural as well as man-made environment.

Nature protection and conservation are in close contact as in the long term areas of nature can only be maintained by eliminating and reducing environmental pollution and the harmful effects.

First, men and their natural and man-made environment must be protected from damages of different nature.

The most significant environmental hazards include:

$\square$ chemical hazards that make harmful effects on man and nature by getting into the food chain from industrial, agricultural and municipal waste similarly to changing our eating habits (preservation, colouring agents);

$\square$ irritating tissues (excessive dust pollution with a mechanical effect which also does harm although it is insoluble in the body);

$\square$ noise and vibration pollution mainly deriving from industry and traffic;

$\square$ radiation (from the nuclear explosion of the atom bomb to decreasing light intensity);

$\square$ damage to fertile land, wildlife, material things, landscape (corrosion, soil erosion);

$\square$ nervous strain, stressors, harmful psychic stimuli.

The pollution of man-made environment could be stopped by global international cooperation all over the world. Environmental pollution has no borders as parts of the biosphere such as water and air join several countries.

Technical solutions to offset harmful environmental effects include:

$\square$ curbing or eliminating harmful emission at the source (processes without harmful emission - waste-free or low waste technologies dust collector wastewater treatment).

$\square$ preventing harmful emissions from converting or spreading in intermediate media - planting forests between industrial quarters and housing estates- proper sensor system.

$\square$ protective instruments at the place of immission-noise protective earplugs, gas masks.

When examining the real causes of environmental pollution we can count in the following factors.

$\square$ lack of green awareness, attitudes, ethics (littering at resorts, felling trees); 
$\square$ objective economic barriers to ceasing some well-known sources of environmental threats (obsolete housing estates);

$\square$ lack of business involvement increases production costs while slowly returning environmental expenditure decreases market competitiveness;

$\square$ objective technological-scientific barriers to eliminating certain sources of hazards (lack of expertise to stop new emissions deriving from the application of new chemical technologies).

The technological-scientific means can only be implemented in practice if the economic, legal and ethical conditions are also ensured.

It is also necessary to determine the value of natural resources and the efficiency of expenditure on environmental protection (Moser et al., 1992).

Experience shows that efficient environmental protection cannot do without the active involvement of the state:

$\square$ State intervention first established the direct (legal) measures and attempted to apply them effectively. These means could be laws, regulations, norms and prohibitions that leave no alternative behind for those concerned, i.e. if the exact instructions are not implemented, it will surely result in legal and administrative sanctions.

$\square$ The legal measures were combined with indirect (economic) ones from the mid-1970 due to their failures and weaknesses. These instruments can be of economic nature: environmental policy fees, taxes, financial support, depositing etc. that can influence the behaviour of those concerned by means of economic interest leaving considering the costs and benefits, advantages and disadvantages discretionary together with independent decision making.

There are measures that cannot be classified into any of the following groups such as negotiating and institutional background; but also moral influence plays a significant role. For corporations, producing environmentally friendly products serves as one of the marketing paraphernalia.

The economic and social conditions of a country or state specify which of these measures serve the political purposes of a coherent economy and environmental protection the best (Farkasné et al., 2013).

\section{EU environmental regulation}

The Fifth Environmental Action Programme of the European Union $(1993,1996)$ entitled Towards sustainability defines sustainable development and its principles. It approaches environmental hazards from a global perspective, affecting the entire planet, such as acid rain and climate change. The objective of the programme is to make new legislative standards on the environment Companies are encouraged to produce green products by economic measures such as tax allowances and consumers are persuaded to buy and use them. Supportive systems are created in IT, education and research and further financial assistance is given by means of different funds and support.

This legislation is special as it covers air pollution, noise, chemical products, water pollution, environmental protection and waste management. In addition, it also deals with protecting surface and underground water and standards are set on spa waters, those for producing fish and shells and drinking water. Measures are also taken to protect the North Sea, the Mediterranean Sea, the Rhine and the Atlantic Ocean from toxic substances. Directives are applied on producing and consuming CFC (chlorofluorocarbon, halogenous carbohydrates, and gases damaging the ozone layer) and also on regulating the noxious fuel emission of vehicles with combustion engine. Maximum noise is set for automobiles, work machines, tractors, airplanes and constructing machines. In all cases must dangerous substances be labelled or differently packaged. In 1986, the European list on existing chemicals was recorded. The collection, reuse and termination of more than 2 bn tonnes of waste generated annually in the $\mathrm{EU}$ are regulated. Limitations are set on transporting waste from one country to another (especially marine oil spills, radioactive waste, the waste of plants dealing with titanium oxide). Tests on animals were also regulated together with the protection of wildlife (Vágási, 2006).

\section{Global environmental regulation}

The global problem of environmental pollution is dealt with by several international organisations, agreements of governments and NGOs (Non-Governmental Organizations) that are tightly correlated with economic growth and development. These organisations drafted the concept of sustainable development which was first defined by the Norwegian Brundtland Commission in 1987 as the criteria of future development following the request of the EU Commission.

According to them, "sustainable development is the development that meets the needs of the present without compromising the ability of future generations to meet their own needs. Yet in the end, sustainable development is not a fixed state of harmony, but rather a process of change in which the exploitation of resources, the direction of investments, the orientation of technological development, and institutional changes are made consistent with future as well as present needs."

Regarding sustainability, the cosmetic industry mainly concentrates on the environmental issues. The Brundland Commission joins countries in order to assist sustainable development, and its three pillars are economy, environment and society.

Figure 1 presents how cosmetic companies manage their ecological footprint. Most attention

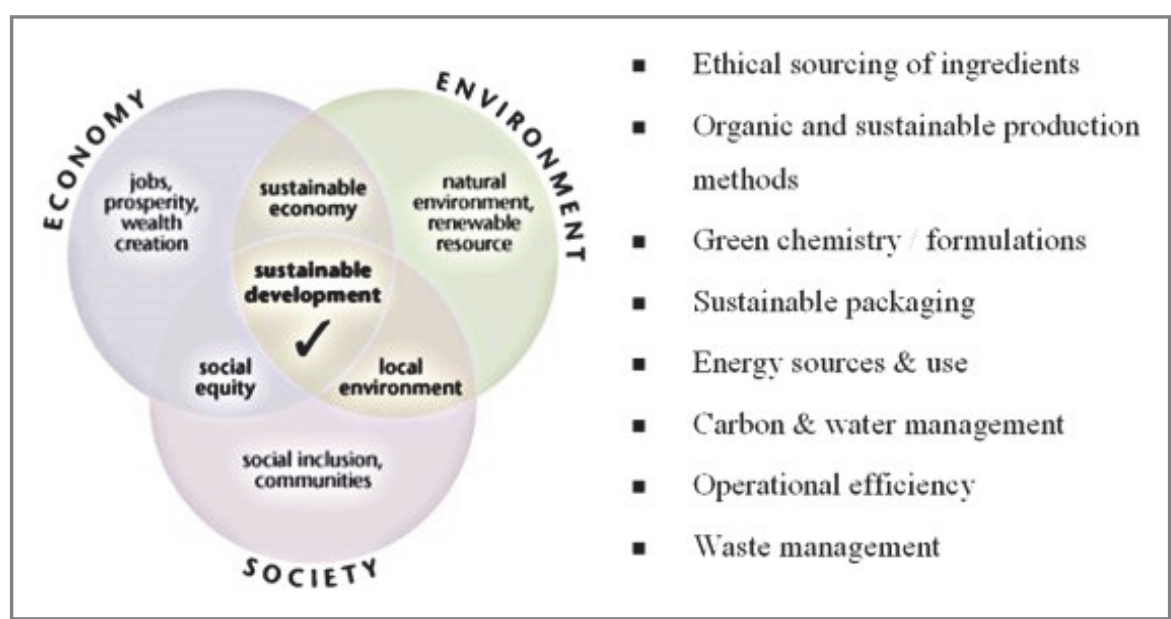

Figure 1 The ecological considerations of sustainability Source: http://www.chemistryviews.org/details/ezine/6915101/The_Greening_of_the_Cosmetics_Industry.html 
is paid to acquiring raw materials, green products and packaging. Certain companies started to trace down the use of water, energy and resources and also pay attention to operational efficiency.

This alternative of development was also on the agenda at the Rio Conference and several other organisations of the UN. It was FAO (Food and Agriculture Organization of the United Nations) that first reacted to the challenges of sustainable development by applying its principles in agriculture.

This approach was first applied in Hungary on 30 May 1995 in the act on the protection of nature accepted by the Parliament (Farkasné et al., 2013).

\section{The role of international cosmetic corporations in reducing environmental load}

For many people, sustainability and cosmetics are two distinct terms. The role of cosmetics in society is often depreciated. A lot of products such as soap, shampoo and toothpaste are essential parts of everyday hygiene. Others such as sun creams and lotions play an important role in skin care and preserving or restoring health. Makeup products like mascara contribute to having more self-confidence. The ancient Egyptians also used cosmetics such as different face and body colours and oil; cosmetics have always been an integral part of society.

To find out how sustainable the cosmetic industry is or how it can tackle the challenges of sustainability related to other industries it is essential to know that large cosmetic companies have always been included in the green list of global companies. In the list of Ethisphere Institute 2014 World's Most Ethical (WME) rank there are seven cosmetic firms: L'Oreal, Shiseido, Colgate-Palmolive, Henkel, Natura Brasil, Kao Corporation and Kimberley-Clark.

Another study of Corporate Knights listed the 100 biggest 'sustainable' companies of the world where, and were in Top 100 (of the best cosmetic companies) in 2014.

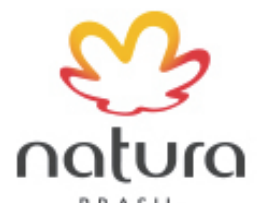

BRASIL

gohmon agohnon
LOREAL

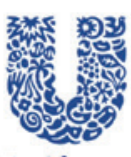

Unilever
The methodology of Corporate Knights includes the evaluation of companies on several environmental protection, social and managerial performance.

During the social impact assessment it turned out that ethical procurement and fair trade are quite frequent. Some companies such as Avon and Grupo Boticario have set up foundations to promote social good. For the time being, a few companies prefer fair client-supplier relationships and different forms of social investments.

Utmost attention should be paid to the economic impact. In reality, not many companies replied the question 'How does the sustainable economic impact of the company operate? One of the reasons is that for many companies business merely means profit by using a term that has nothing to do with sustainability. However, there are several opportunities for the companies to deal with their economic impacts. One of them is to pass down returns not only on their shareholders but also their equity owners. Regarding the complex measuring of sustainability the practical approaches to manage environmental, social and economic impacts are rather complicated and they were also discussed at the Sustainable Cosmetics summit held in Paris on 24-26 November 2014.

'Green' components are available in a greater number. As sustainable considerations are playing a more significant role in corporate life, cosmetic companies invest in green formations. The widening range of green raw materials will become available for manufacturers. This development has resulted in further innovation and the enlargement of the natural and organic cosmetic market. In addition, the quality and performance of the products have also become better as more and more green basic materials are available for manufacturing and use. Nowadays almost all large chemical companies have natural/organic components in their portfolio. A decade ago these companies were not concerned in this niche segment that was dealing with the raw materials supplied to most natural based companies.

The availability of the green raw materials of large chemical companies such as BASF, Evonik and Rhodia has urged the large cosmetic companies to develop their natural and organic cosmetic lines. Almost every company has such natural and organic lines. In 2010, Johnson \& Johnson presented Johnson's Natural, the natural body lotion products for babies and children. In Europe, Beiersdorf, Unilever, Henkel and Garnier manufacture such organic and natural products that are own brand labelled.

Several large cosmetic companies have introduced organic and natural cosmetic lines as they have less economic impact and load than the traditional products. The producers of natural and biochemical cosmetics try to avoid the synthetic components and their carbon dioxide emission is also lower in manufacturing. of course, the manufacturers have green chemical processes during production that include sustainable production methods, as well. In real, for some cosmetic companies the easiest way to become green is the introduction of natural/ organic lines (http://www.chemistryviews.org/ details/ezine/6915101/The_Greening_of_the_ Cosmetics_Industry.html).

Figure 2 shows that in 2014 Asia-Pacific has the biggest share in the natural personal care market with a global market share of above $35 \%$. Europe is the second; Brazil the third and the USA have the fourth place.

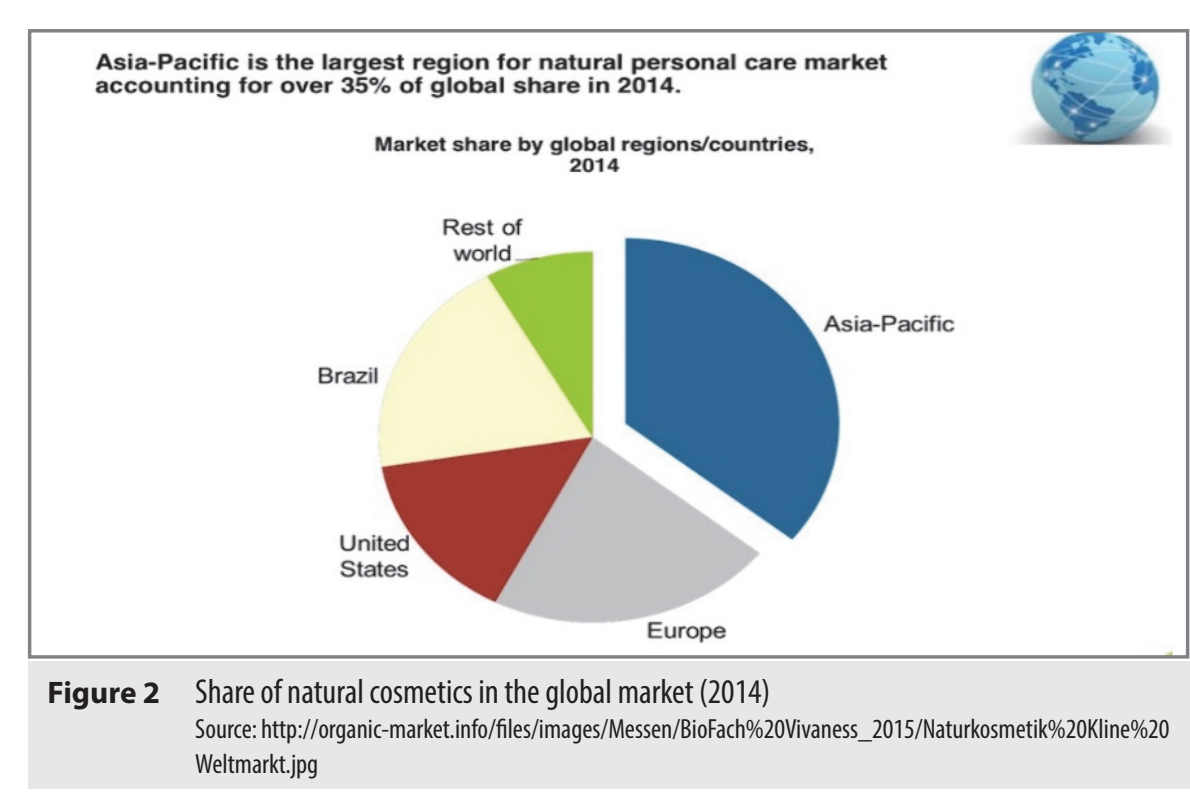




\section{Sustainable considerations in the European and the global cosmetic industry}

$\square$ Regarding design and appearance, one of the significant factors of cosmetics is the reduction of the environmental load. The entire supply chain has been transformed due to natural basic materials, packaging and technologies. Environmental consciousness, health consciousness and natural look have become the central issues of the supply chain.

$\square$ In terms of the procurement of raw materials and basic commodities the importance of environmental and social criteria has increased concerning the components and wrapping of products. The basic objectives include minimising deforestation, biodiversity and ensuring the diversity of different species. Palm oil from the palm trees and lavender oil are gaining more importance as raw materials while plastic packaging is losing ground. Biomass, plastic with an organic basis and polyethylene of organic sources are becoming more significant. Measures have also been taken to protect bees. Several cosmetic products contain raw materials originating from bees like honey compounds and wax. These cosmetic products are widely used by smaller-scale cosmetic manufacturers but now the protection of the species is a priority.

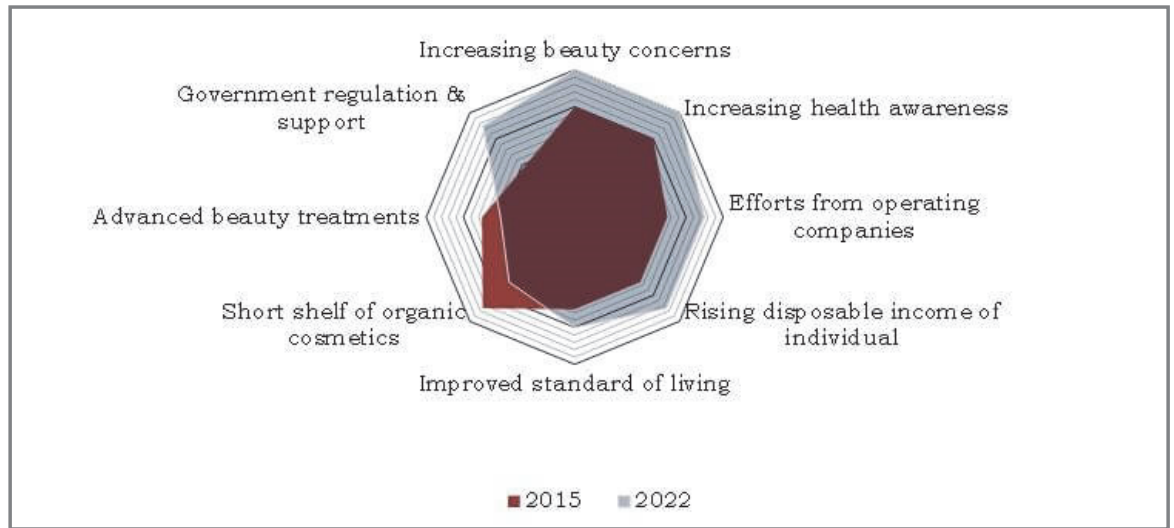

Figure 3 Top factors impacting world personal care and cosmetics market Source: https://www.alliedmarketresearch.com/organic-personal-care-and-cosmetic-products-market

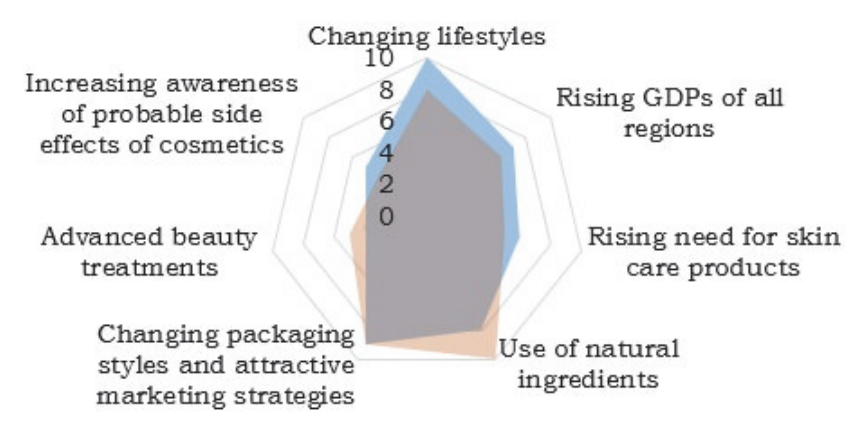

$2014=2022$

Figure 4 Top factors impacting the global cosmetics market Source: https://www.alliedmarketresearch.com/cosmetics-market $\square$ It is important to identify and measure the environmental protection factors together with the use and development of such components, work processes and wrapping materials that cause less load and harm to the environment (https://www. cosmeticseurope.eu/cosmetics-industry/).

$\square$ In terms of manufacturing technologies that reduce energy use and water use, waste generation and rejects are used in manufacturing cosmetics. The unlimited natural resources are prioritized such as solar and wind energy, collecting rain or recyclable packaging materials, which are just a few examples for environmentally conscious behaviour.

Figure 3 presents that cosmetic corporations will play a significant role in promoting health consciousness by 2022 due to governmental regulations and support, which will affect the running of operative cosmetic companies. The increase in disposable income from the consumers' part will have a beneficial impact on buying health conscious products and raising the living standards. The expiry date of organic cosmetics is shorter on the basis of a 2015 survey, which is due to its chemical-free nature. Modern cosmetic treatments have a slighter significance in 2015 that they will in 2022 according to the forecast.

Figure 4 shows the changes of different lifestyle in 2014 and the 2022 forecast. In 2022 natural compounds will be preferred so the global demand for organic cosmetics will rise. Changes in wrapping styles and attractive marketing strategies will also gain more ground, which will result in using more natural materials to promote health consciousness and environmental protection. Demand for facial care products will also rise in line with the changing lifestyles, which will lead to the increase of regional GDP. By 2022 the growth in the number of cosmetic treatments is moderate. The side effects of cosmetics will diminish with the appearance of natural cosmetics due to the use of natural active agents.
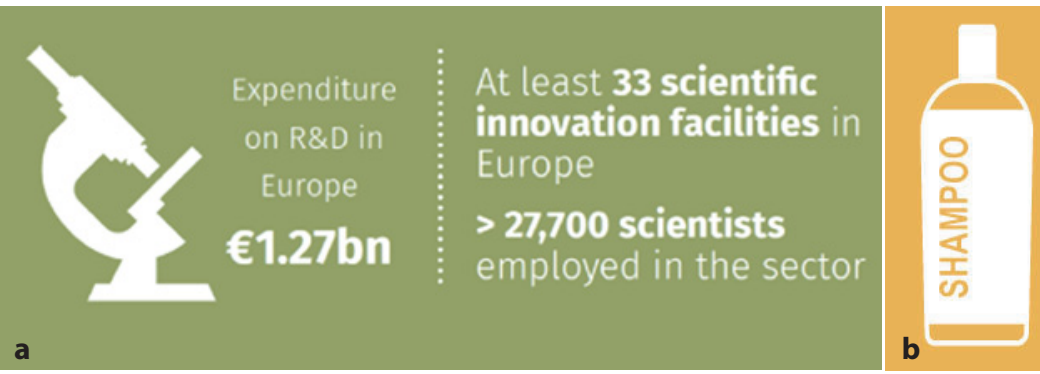

2014/15 - Shampoos: the most active area for innovation (globally)

Figure 5 a - Research\&science, $b$ - Innovation activity Source: https://www.cosmeticseurope.eu/cosmetics-industry/ 
Figure $5 a$ illustrates that 1.27 bn euro was spent on R\&D in the cosmetic industry in Europe in 33 cosmetic research centres and establishments by employing 27,700 researchers and scientists.

$\square$ Concerning consumer use new types of shampoos have appeared on the market with more concentrated formula. They are 2 in 1 products: shampoo and conditioner, Head \& Shoulders. According to the survey of Cosmetics Europe shampoos are made from natural raw materials by using environmentally friendly technologies, manufacturing, transportation and packaging. Figure $5 \mathrm{~b}$ presents the innovation activities related to the production and marketing of shampoos. In 2014-2015 shampoos were the most active areas of innovation activities globally. Nineteen percent of all innovation activities are beauty innovation activities.

$\square$ Concerning transportation, railways are preferred to roads and ships to airplanes to decrease environmental damage. Hybrid or electric vehicles, larger trucks and new compact products are used to this end.

$\square$ The use of biodegradable, reusable and recycled packaging materials with 'organic' label is imperative concerning the points of customer care and contact with the customers.

All this serves to create a safe and protected environment for the future generations with considerations to the principle of sustainable development in the entire product life cycle. Dedication is a must to prevent greenhouse gases from rising in the air and reduce acid rain as well as stop global warming by producing goods made from natural sources.

The buildings of the cosmetic factories also strive to use geothermic, green energy and renewable sources. They try to reduce the amount of waste generated in production, the number of rejects and they make recycled, refillable boxes with an organic appearance to stop loading the

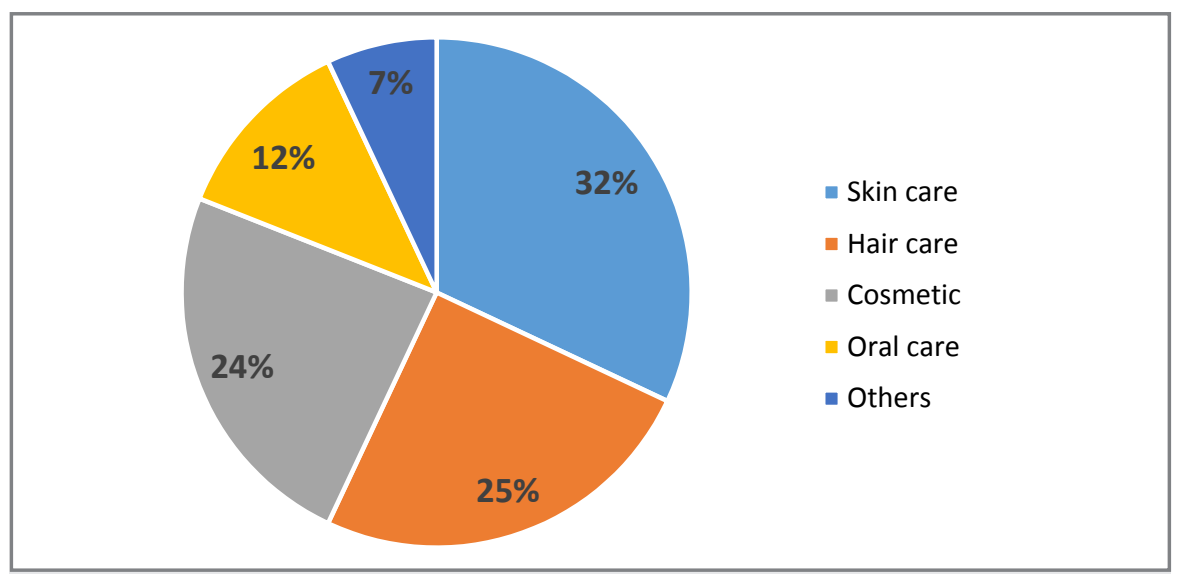

Figure 6 Global organic personal care market revenue share, by product, 2015 (\%) Source: Authors' own editing based on http://www.grandviewresearch.com/industry-analysis/organic-personalcare-market

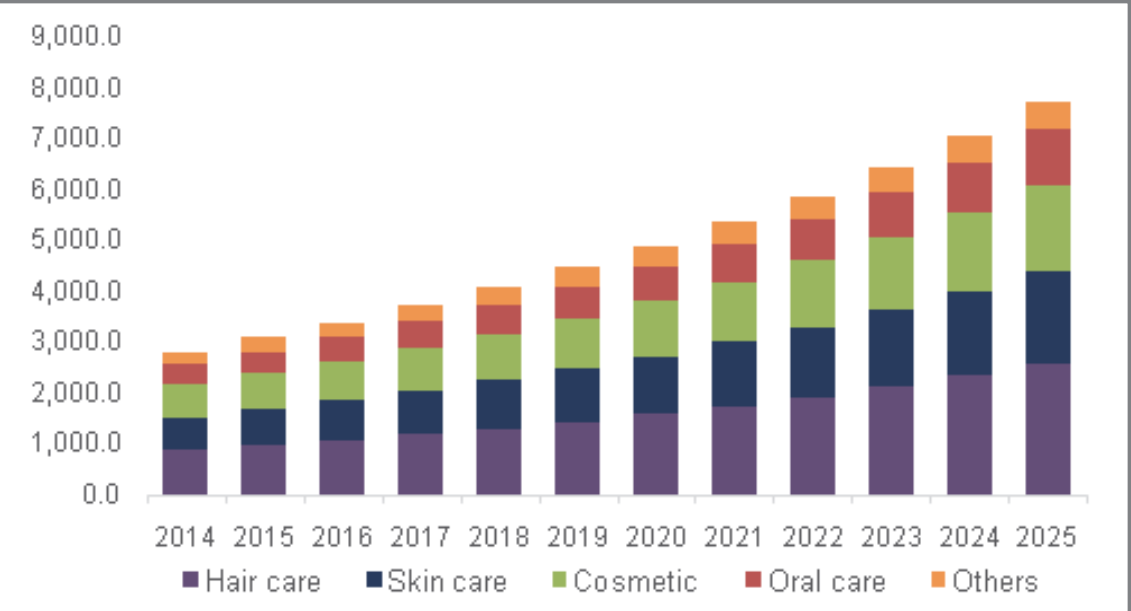

Figure 7 US organic personal care market revenue, by product, 2014-2025 (USD million) Source: http://www.grandviewresearch.com/industry-analysis/organic-personal-care-market

environment. Water consumption is to be curbed to nearly half to prevent excessive material and energy use while manufacturing (https://www. cosmeticseurope.eu/files /4214/9738/9237/ CE__Environmental_Sustainability_Key _Facts.pdf, https://www.cosmeticseurope. eu/files/8614/9738/2777/CE_Socio-economic _development_and__environmental_ sustainability_report_2017.pdf).

The world's cosmetic market is dedicated to natural, herbal based personal care by ensuring opportunities of innovations and developing new products for the manufacturers that pose less threat to the environment and satisfy consumers' needs.

$\square$ The processes of procurement, manufacturing and transportation are also directed at environmental consciousness and reducing the ecological footprint.

The trends of environmental consciousness and health consciousness are very dominant in the cosmetic industry, which is reflected in the entire product life cycle and the everyday cosmetic product use of consumers (https://www. alliedmarketresearch.com/cosmetics-market).

Figure 6 shows that globally the most sought after products are organic skin care followed by the natural based hair care and cosmetics (make-up). The share of oral care is half the hair care. Half of the demand for oral care is the demand for other cosmetics.

Based on Figure 7, mainly organic hair care products are sold well in the United States of America. This is supported by future forecast. Organic skin care and cosmetics are at the second place. Demand for oral care amounts to half of that of cosmetics/skin care, while others make up approximately half of the latter product groups.

\section{Alternatives for environmentally conscious consumers with the purchase and preference of organic cosmetics}

Natural and organic cosmetics have made use of the sustainability trend. These products contain organic and natural compounds that derive from plants and the objective is to avoid synthetic chemicals such as parabens, phthalates and natrium lauryl sulphate.

Figure 8 presents that the global market of natural and organic cosmetics increased to $9.1 \mathrm{bn}$ dollars in 2011 as of nearly 5 bn in 2005 and turnover reached 10.4 bn dollars in 2013 and this advancement is steady even nowadays.

The most important reason for the customers' buying such products is certain health 


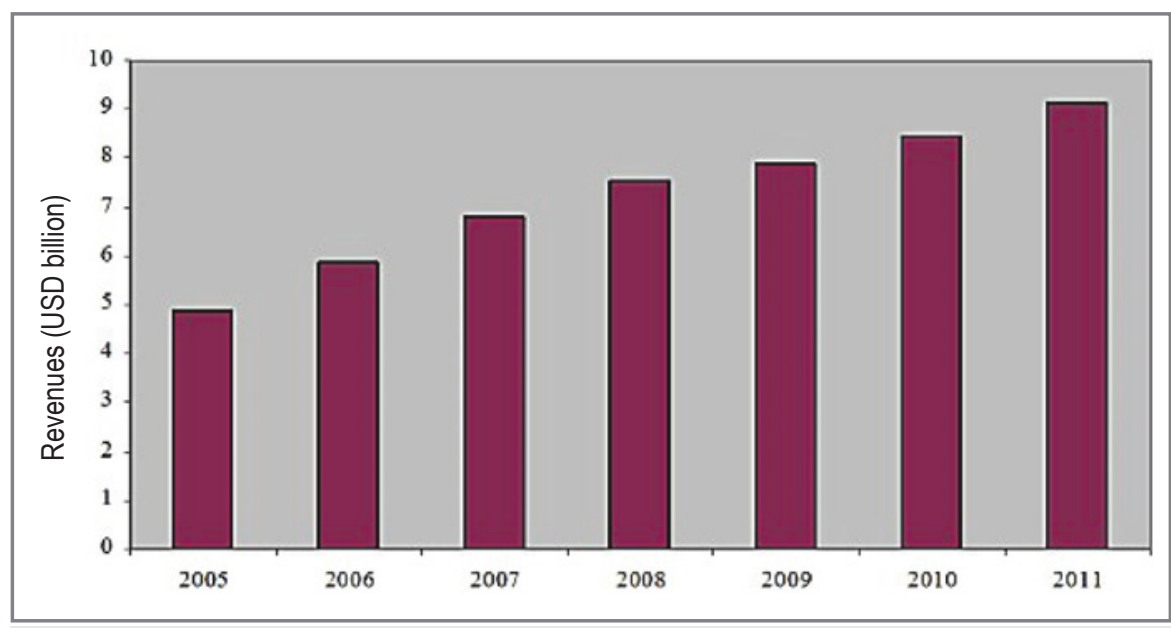

Figure 8 The growing market of natural and organic care Source: http://www.chemistryviews.org/details/ezine/6915101/The_Greening_of_the_Cosmetics_Industry

and security concerns, i.e. whether sustainability contributes to the success of the product. In 2005, consumer's demand for natural and organic cosmetics was great but few products met the requirements of the consumers. There are no substitutes for several raw materials such as synthetic preservatives, emulsificators and surface active agents. The present substitutes are unable to perform the functions of their synthetic equivalents (http://www.chemistryviews.org/details/ezine/6915101/The_Greening_ of_the_Cosmetics_Industry.html).

A currently important trend is the interest in the natural compounds of cosmetics in the consumer market. Demand for herbal based products will decrease demand for other products. Consumers are looking for products that entirely meet their personal expectations more and more directed at health and environmental consciousness (https://www.alliedmarketresearch.com/cosmetics-market).

What makes natural cosmetics natural? (How can the consumer decide if a certain cosmetic product is organic or not?)

The different adjectives like eco, organic, natural, made form herbs and plants practically are identical, meaning the same. They are all cosmetics made from natural materials that are natural, floral, can be found in nature like algae or minerals. Natural and organic mean that the plants used were produced free from chemicals.

The origins of a cosmetic item, regardless of it natural components, are included in INCI (International Nomenclature of Cosmetic Ingredients).

A quicker and a simpler method is looking for certificates. As the logos of different certificates cannot be displayed on the cosmetic products without permission, we can say that they certify that the cosmetics were made from natural components.

Such logos can be as follows:

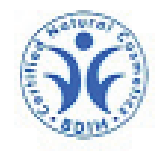

1.

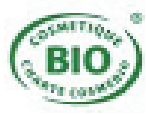

2.

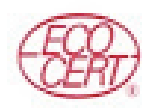

3.

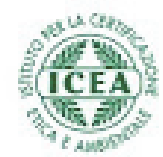

4.

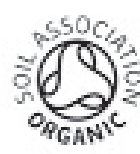

5.
Acknowledged cosmetic certificates in Europe include the German BDIH (1.), the French Cosmebio (2.) and Ecocert (3.), the Italian Icea (4.) and the English Soil Association (5.). Due to the cooperation between organisations (1.) - (5.), COSMOS (COSMetics Organic Standard) was established at the beginning of 2010 with the objective of unifying the labelling rules of natural cosmetics in Europe. The COSMOS Natural label must be carried by such cosmetics that are free from parabens, genetically modified compounds and most petroleum derivatives. While producing different creams, certain environmental regulations must be kept. A cosmetic product can only have COSMOS Organic label if minimum $95 \%$ of its compounds deriving from agriculture is organic and these compounds make up at least $20 \%$ of the cream.

Finally, it comes to the consumers what they prefer... (http://blog.kremmania.hu/2011/03/mitolnatur-naturkozmetikum.html).

\section{Conclusion}

Our environment has become more and more contaminated globally during the course of time primarily due to the destruction caused by human activities. This tendency can only be stopped by means of international cooperation or on a global level in which local initiations have a great role similarly to the individual level as all of us must do something to protect the environment starting from avoiding littering in the forest to selective waste collection. Everybody is responsible for the environment so we must not forget about it. Many of us think that one or two pieces of paper will not damage the environment but if we consider that more than 7 billion people live on Earth and let us assume everybody does the same thing... where would it lead? Our planet would become a junkyard. And this is only one problem. In addition, there are industrial problems and disasters deriving from inadequate transportation such as sinking ships while transporting oil.

The large international cosmetic firms have started marching on the 'green' road. They are committed to using natural and organic materials, work processes and technologies on the international market under the umbrella of sustainable development by showing examples for the smaller ones.

The consumers' way of thinking has also been transformed significantly. People are eager to live in a more health- and environmentally conscious way which is why they opt for natural care instead of cosmetics of high chemical content.

\section{References}

ABRAHAMSON, D. E. 1989. The challenge of global warming, Island Press, USA, 1989, pp. 35-43.

ALLIED MARKET RESEARCH REPORT 2014-2022. https:// www.alliedmarketresearch.com/cosmetics-market; https://www.alliedmarketresearch.com/organicpersonal-care-and-cosmetic-products-market

BENNETT, S. J. - FREIERMAN, R. - GEORGE S. 1993. Corporate realities \& environmental truths. USA : John Wiley \& Sons Inc., 1993, pp. 1-29.

BORELLI, P. 1988. Crossroads, Environmental priorities for the future. Washington D.C., USA : Island Press, 1988, pp. 171-197.

BUZAS, G. - FABULA, L. - HAZAYNÉ, L.É. - HUBAl, J. - KEREKES, S. - KOBJAKOV, Zs. - KOVÁCS, K. - MEDVÉNÉ, SZ. K. - MOCSY, F. - VASS, N. 2004. A környezet-gazdaságtan alapjai. Perfekt Gazdasági Tanácsadó. Budapest : Oktató és Kiadó Részvénytársaság, 2004, pp. 33-71.

COSMETICS EUROPE. The personal care association. $\quad$ https://www.cosmeticseurope. eu/cosmetics-industry/, https://www. cosmeticseurope.eu/files/4214/9738/9237/ CE_Environmental_Sustainability_Key_Facts.pdf; 
https://www.cosmeticseurope.eu/files/8614/9738/2777/CE_Socio-economic development_and_environmental_sustainability_report_2017.pdf; http://www. grandviewresearch.com/industry-analysis/organic-personal-care-market

FARKASNÉ, F. M. - MOLNÁR, J. 2013. Mikroökonómia. Szaktudás Kiadó Ház, BP., 2013, pp. 346-348.

IBISWORLD INDUSTRY REPORT 32562. 2011. Cosmetic \& Beauty Products Manufacturing in the US, November, 2011. https://colgate-palmolive.wikispaces.com/file/ view/32562_Cosmetic_\%26_Beauty_Products_Manufacturing_in_the_US_ Industry_Report $\% 5 B 1 \% 5 \mathrm{D}+(1)$.pdf

KERÉNYI, A. 1995. Általános környezetvédelem - Globális gondok, lehetséges megoldások. Szeged : MOZAIK Oktatási Stúdió, 1995, pp. 67-268.

MOSER, M. - PÁLMAl, Gy. 1992. A környezetvédelem alapjai. Nemzetközi Tankönyvkiadó, BP, 1992, pp. 25-34.

ORGANIC COSMETIC MARKET SHARE. 2014. http://organic-market.info/files/images/ Messen/BioFach\%20Vivaness_2015/Naturkosmetik\%20Kline\%20Weltmarkt.jpg

OTTMAN, J. A. 1993. Green marketing. Challenges\&opportunities for the new marketing age. Lincolnwood (Chicago), Illinois, USA : Ottman Consulting, Inc., 1993, pp. 2-9, 27-29,74-78.

RÁCZ, J. http://blog.kremmania.hu/2011/03/mitol-natur-naturkozmetikum.html

SAHOTA, A. 2014. Sustainability: How the cosmetics industry is greening up. USA : John Wiley \& Sons, Ltd., 2014, pp. 18-30, 129-139, 155-162, 198-200, 218-225, 242244, 292-296, 301-308.

SAHOTA, A. The greening of the cosmetics industry. http://www.chemistryviews.org/ details/ezine/6915101/The_Greening_of_the_Cosmetics_Industry.html
STEADE, R.D. - LOWRY, J.R. - GLOS, R.E. 1984. Business, Its nature and environment. Dallas, USA : South-Western Publishing Co., 1984, pp. 30-35, 189-210, 247-258.

TUCKER, W.T. 1967. Foundations for a theory of consumer behaviour. USA : Holt, Rinehart and Winston, Inc., 1967, pp. 23-32.

VÁGÁSI, M. 2000. A fenntartható fogyasztás és a környezettudatos fogyasztói magatartás. In Marketing \& Menedzsment, 2000, no. 6, pp. 39-44.

ZIKMUND, W.G. - MIDDLEMIST, R.D. - MIDDLEMIST, M.R. 1995. Business, The American challenge for global competitiveness. Illinois, USA : Richard D. Irwin, Inc., Burr Ridge, 1995, pp. 41-69.

\section{Contact address}

Nora Amberg, PhD student

Szent István University

Faculty of Economics and Social Sciences

Department of Marketing Methodology

H-2100 Gödöllő, Páter Károly street 1

e-mail: nora.amberg@gmail.com 